\title{
Germ Line
}

National Human Genome Research Institute (NHGRI)

\section{Source}

National Human Genome Research Institute (NHGRI). Germ Line.

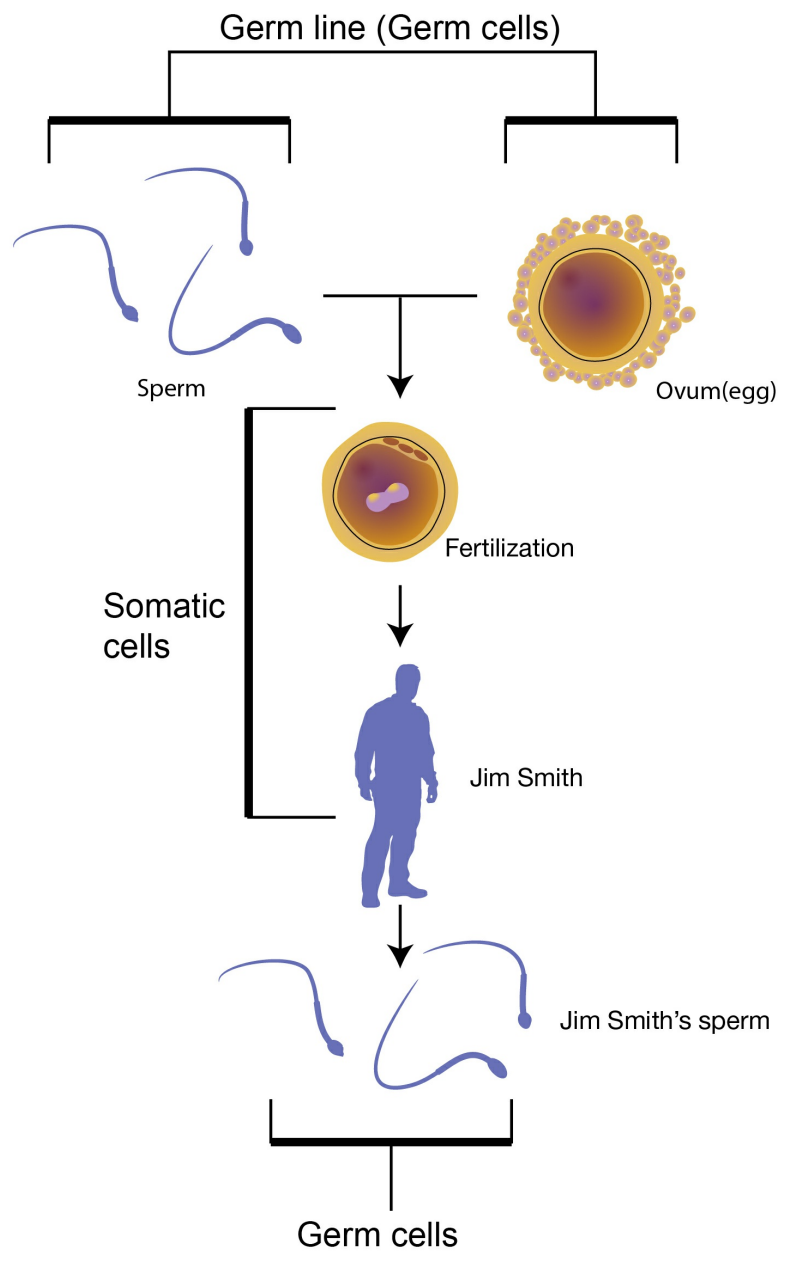

A germ line is the sex cells (eggs and sperm) that are used by sexually reproducing organisms to pass on genes from generation to generation. Egg and sperm cells are called germ cells, in contrast to the other cells of the body that are called somatic cells. 